\title{
EVALUATION OF ANTITUMOR ACTIVITY OF SOME 4-AMINOPIPERIDINE DERIVATIVES — LOW MOLECULAR WEIGHT HSP7O INHIBITORS — ON TRANSPLANTABLE MOUSE TUMORS
}

Aldobaev VN ${ }^{1} \otimes$, Mikhina $\mathrm{LV}^{1}$, Present $\mathrm{MA}^{2}$

${ }^{1}$ Research Centre for Toxicology and Hygienic Regulation of Biopreparations of FMBA, Serpukhov, Russia

2 Zelinsky Institute of Organic Chemistry, Moscow, Russia

\begin{abstract}
Low molecular weight compounds targeting chaperone proteins Hsp90 and Hsp70 have opened up a new avenue in the therapy of neoplasms. In 2020 , we tested $3 \mathrm{Hsp} 70$ inhibitors from the class of 4-aminopiperidine derivatives for their antitumor activity on in vivo models. The list of the tested compounds included $\mathrm{N}$-(2-chlorobenzyl)-N-ethyl-1-(2-(methylthio)pyrimidin-4-yl)piperidin-4-amine (compound 1), 4-((methyl(1-(2-(methylthio)pyrimidin-4-yl) piperidin-4-yl)amino)methyl) benzonitrile (compound 2) and N-(2,6- dichlorobenzyl)-1-(1-(2-(ethylthio)pyrimidin-4-yl)piperidin-4-yl)-N-methylmethaneamine (compound 3). The aim of this study was to compare the efficacy of 4-aminopiperidine derivatives in vivo using the models of transplantable murine L1210 lymphocytic leukemia and B16 melanoma. Compounds 2 and 3 used in combination with cyclophosphamide exhibited high cytotoxic activity $(p=0.05)$ against L1210 leukemia (an $80-82 \%$ increase in survival time) and B16 melanoma (98-99.7\% tumor growth delay). For L1210 lymphocytic leukemia, compounds 2 and 3 used in combination with cyclophosphamide fell into the low (+) therapeutic potential category. For B16 melanoma, compounds 1, 2 and 3 used in combination with cyclophosphamide fell into either low (+) or moderate (++) therapeutic potential categories. On the whole, the tested doses of the compounds used in combination with cyclophosphamide hold promise for the therapy of L1210 leukemia and B16 melanoma in mouse models. Our findings confirm the potential of low molecular weight Hsp70 inhibitors for combination chemotherapy against cancer.
\end{abstract}

Keywords: heat shock proteins, Hsp70 inhibitors, transplantable tumor, L1210 leukemia, B16 melanoma

Funding: the study was carried out under the State Assignment for FMBA № 22.001.18.800.

Author contribution: Aldobaev VN planned the experiment, summarized its results and wrote this manuscript; Mikhina LV carried out the experiment in animal models; Present MA synthesized the tested compounds.

Compliance with ethical standards: the study was approved by the Ethics Committee of the Research Centre for Toxicology and Hygienic Regulation of Biopreparations (Protocol № 695 dated November 12, 2019). Housing conditions met the requirements of Sanitary Regulations 2.2.1.3218-14 (Sanitary and Epidemiological Requirements for Design, Equipment and Maintenance of Vivarium Facilities) and the guidelines provided in the Guide for Care and Use of Laboratory Animals (ILAR publication, 1996, National Academy Press, USA).

$\triangle$ Correspondence should be addressed: Vladimir N. Aldobaev

Lenina, 102A, pos. Bolshevik, Moscow oblast,142283; aldobaev@toxicbio.ru

Received: 13.02.2021 Accepted: 12.03.2021 Published online: 21.03.2021

DOI: $10.47183 /$ mes.2021.009

\section{ОЦЕНКА ПРОТИВООПУХОЛЕВОЙ АКТИВНОСТИ РЯДА ПРОИЗВОДНЫХ 4-АМИНОПИПЕРИДИНА, НИЗКОМОЛЕКУЛЯРНЫХ ИНГИБИТОРОВ НSР70, НА ПЕРЕВИВАЕМЫХ ОПУХОЛЯХ МЫШЕЙ}

В. Н. Алдобаев ${ }^{1}$, Л. В. Михина', М. А. Презент ${ }^{2}$

${ }^{1}$ Научно-исследовательский центр токсикологии и гигиенической регламентации биопрепаратов Федерального медико-биологического агентства, Серпухов, Россия

2 Институт органической химии имени Н. Д. Зелинского, Москва, Россия

\begin{abstract}
Применение низкомолекулярных агентов, мишенью которых являются молекулярные шапероны Hsp90 и Нsp70, стало основой для целого направления в терапии новообразований. В 2020 г. была проведена сравнительная оценка противоопухолевой активности на моделях іn vivo трех производных 4-аминопиперидина ингибиторов Нsp70: N-(2-хлоробензил)-N-этил-1-(2-(метилтио)пиримидин-4-ил)пиперидин-4-амина (№ 1); 4-((метил(1(2-(метилтио)пиримидин-4-ил)пиперидин-4-ил)амино)метил) бензонитрила (№ 2); N-(2,6-дихлорбензил)-1-(1-(2-(этилтио)пиримидин-4-ил)пиперидин-4-ил)$\mathrm{N}$-метилметанамина (№ 3). Целью работы было провести сравнительные испытания эффективности производных 4-аминопиперидина іп vivo на перевиваемых опухолях мышей. Противоопухолевую активность исследуемых веществ изучали на моделях лимфоидной лейкемии L1210 и меланомы В16. Субстанции № 2 и 3 продемонстрировали высокую статистически значимую (p=0,05) активность в случае комбинированной терапии с циклофосфамидом для лейкоза L1210 (увеличение продолжительности жизни - 80-82\%) и для меланомы B16 (торможение роста опухоли 98-99,7\%). В случае L1210 вещества № 2 и 3 в комбинации с цитостатиком попали в низшую категорию перспективности «+» для модельных лейкозов животных. В случае В16 вещества № 1-3 в комбинации с цитостатиком попадали либо в низшую категорию перспективности «+», либо в категорию «++» для модельных солидных опухолей животных. Испытанные дозировки субстанций продемонстрировали обещающие результаты лечения в комбинации с циклофосфамидом на перевиваемых опухолях лимфоидной лейкемии L1210 и меланомы B16 мышей. Полученные эффекты подтверждают перспективность применения низкомолекулярных ингибиторов Нsp70 в составе комбинированной химиотерапии в онкологии.
\end{abstract}

Ключевые слова: белки теплового шока, ингибиторы Hsp70, перевиваемая опухоль, лейкемия L1210, меланома B16

Финансирование: государственное задание ФМБА № 22.001.18.800.

Вклад авторов: В. Н. Алдобаев - написание статьи, обобщение результатов, общее планирование работ; Л. В. Михина - обеспечение экспериментов на животных-опухоленосителях, отработка моделей; М. А. Презент - синтез субстанций для сравнительных испытаний.

Соблюдение этических стандартов: исследование одобрено этическим комитетом НИЦ ТБП (ветеринарный протокол № 695 от 12 ноября 2019 г.); условия содержания и уход за животными соответствовали нормативам СП 2.2.1.3218-14 «Санитарно-эпидемиологические требования к устройству, оборудованию и содержанию экспериментально-биологических клиник (вивариев)», а также условиям, приведенным в руководстве «Guide for Care and Use of Laboratory Animals» (ILAR publication, 1996, National Academy Press, USA).

$\searrow$ Для корреспонденции: Владимир Николаевич Алдобаев ул. Ленина, д. 102A, пос. Большевик, Московская область, 142283; aldobaev@toxicbio.ru

Статья получена: 13.02.2021 Статья принята к печати: 12.03.2021 Опубликована онлайн: 21.03.2021

DOI: $10.47183 /$ mes.2021.009 
Low molecular weight compounds targeting molecular chaperones like Hsp90 and Hsp70 have opened up a new avenue in the therapy of neoplasms. Heat shock proteins Hsp90 and Hsp70 are overexpressed in many tumors, which explains selective accumulation of Hsp90 inhibitors in tumor tissue [1]. Inhibited expression and/or reduced functional activity of heat shock proteins result in the accumulation of damaged, partially denatured, functionally altered proteins in the cell. It is hypothesized that Hsp90 and Hsp70 might enhance the anticancer effect of cytotoxic drugs and help to overcome drug resistance when used in combination with chemotherapy agents. Some recent publications [2-4] discuss the synthesis of Hsp70 inhibitors, the small molecules designed by means of molecular docking. An article [4] describes the synthesis of 67 candidate Hsp70 inhibitors from the class of 4-aminopiperidine derivatives [4], whose activity was tested on cell cultures in vitro. The article provides information on the kinetic rate constants for each compound measured by surface plasmon resonance and evaluates the inhibitory effect of the synthesized compounds on Hsp70 ATPase activity. Another publication [5] describes an alternative technique for the synthesis of some of the 4-aminopiperidine derivatives from [4], including 1-(2-alkylthiopyrimidin-4-yl)piperidin-4-N-alkyl,Nhetaryl/aryl amines. The proposed technique allowed us to obtain larger combinatorial libraries for further screening tests on cell cultures and the subsequent optimization of candidate cytotoxic drugs.

In 2018-2019, our team synthesized a collection of 4-aminopiperidine derivatives, which partially overlapped with the collection described in [4] and performed an in vitro screening test of their cytotoxic activity on cell cultures. Three 4-aminopiperidine derivatives were selected for further in vivo tests on animal tumor models. The antitumor activity of the synthesized compounds was studied on transplantable mouse lymphocytic leukemia (L1210) and solid melanoma tumors (B16). Cyclophosphamide was used as a positive control following recommendations in [8] and as a treatment against induced cancers.

\section{METHODS}

\section{Laboratory animals}

The tumors were maintained in female $\mathrm{C}_{57} \mathrm{Bl} / 6$ and DBA/2 mice. The specific activity of the synthesized compounds was assessed in vivo on inoculated female hybrid BDF1 mice $\left(\mathrm{C}_{57} \mathrm{Bl} / 6 \times \mathrm{DBA} / 2\right)$. At the beginning of the study, the mice weighted 20 to $30 \mathrm{~g}$. The animals were purchased from the Research Center for Biomedical Technology, FMBA (the branch of Stolbovaya breeding nursery, Moscow region). The animals were housed in a conventional room in the absence of other animal species.

The mice were kept in $26 \times 17 \times 12 \mathrm{~cm}^{3}$ polycarbonate cages (Tecniplast; Italy) at 6 animals per cage. The cages were fitted with stainless-steel wire lids and in-built feed hoppers, a stainless-steel divider to separate the food zone, and label holders. The cages were arranged on stainless steel racks (Tecniplast; Italy).

Wood chips were used as a bedding (Laboratorkorm; Russia); the bedding was 5-10 mm thick.

The animals were allowed ad libitum access to a standard chow diet (Kombikorm PK-120 for laboratory rats, mice and hamsters by Laboratorkorm; Russia). The food was supplied via a food hopper.

The animals also had ad libitum access to filtered tap water supplied in standard drinking bottles with steel caps and sipper tubes. Water quality satisfied Sanitary Regulations 2.1.4.1074-01 (updated on April 2, 2018). Filtering was necessary to avoid water contamination that could have affected the results of the study.

The mice were housed under artificial $12: 12$ light-dark conditions in a controlled environment at $20-26{ }^{\circ} \mathrm{C}$ and $30-70 \%$ air humidity. The temperature and humidity in the room were maintained by an automated climate control system. The air exchange rate was 15 air changes per hour. Before the experiment, the animals were quarantined for 14 days.

\section{Maintenance of transplantable tumors}

The antitumor activity of the synthesized compounds was studied in vivo using the transplantable murine lymphocytic leukemia (L1210) and solid B16 melanoma models.

Cancer cell lines were provided by Blokhin Cancer Research Center (Russia), where they had been cryopreserved in $1 \mathrm{ml}$ ampoules and stored in liquid nitrogen. The cells were shipped in liquid nitrogen. Protocols used to recover the cryopreserved cells were the same for both cancer cell lines. Briefly, the ampoules were retrieved from liquid nitrogen and left in an incubator at $37^{\circ} \mathrm{C}$ for $30 \mathrm{~min}$. After that, $0.5 \mathrm{ml}$ of the cell suspension was administered to each animal. Lymphocytic leukemia L1210 was maintained in DBA/2 mice, B16 melanoma was maintained in $\mathrm{C}_{57} \mathrm{Bl} / 6$ mice. The neoplasms were maintained by inoculation. To maintain L1210 lymphocytic leukemia, intact mice were inoculated intraperitoneally with $0.3 \mathrm{ml}$ of L1210 ascitic fluid derived from hosts on days 5 or 6 and diluted with normal saline 1 : 60. To keep B16 melanoma viable, intact mice were subcutaneously inoculated with $0.5 \mathrm{ml}$ of B16 melanoma preparation derived from hosts on day 16-20 (1 g of the tumor was homogenized in $10 \mathrm{ml}$ of normal saline).

\section{Treatment}

Lymphocytic leukemia and solid melanoma cells were transplanted to female BDF1 mice $\left(\mathrm{C}_{57} \mathrm{Bl} / 6 \times \mathrm{DBA} / 2\right)$ using the same protocol as for tumor maintenance. For inoculations, we used cells that had undergone at least 2 passages in mice after thawing. Therapy against L1210 lymphocytic leukemia was initiated $24 \mathrm{~h}$ after inoculation; therapy against B16 melanoma was initiated $48 \mathrm{~h}$ after inoculation [6]. As part of the experiment, we determined effective cyclophosphamide doses and regimens against the induced murine cancers. The choice of cyclophosphamide as a positive control for the L1210 model was dictated by the results of our previous study [7]. With the melanoma model, the choice of cyclophosphamide was based on our practical experience. Mice inoculated with L1210 cells received IM injections of $50 \mathrm{mg} / \mathrm{kg}$ cyclophosphamide twice, $24 \mathrm{~h}$ and $72 \mathrm{~h}$ after inoculation. This treatment regimen allowed us to prolong survival by an average of $31-43 \%$, as compared with the negative control group (NC). For mice inoculated with L1210 lymphocytic leukemia cells, survival times ranged from 2 to 3 weeks.

Mice inoculated with B16 melanoma cells received 3 IM injections of $80 \mathrm{mg} / \mathrm{kg}$ cyclophosphamide on days 2, 5 and 9 after inoculation. This regimen resulted in 62-100\% tumor growth delay during the observation period (1 month) and prolonged survival by $10-23 \%$, as compared with the NC group. For mice inoculated with B16 melanoma cells, survival times ranged from 4 to 5 weeks.

For the experiment, 4-aminopiperidine derivatives were formulated as water-soluble hydrochlorides. Mice with lymphocytic leukemia received daily injections of 
Table 1. Primary tests of antitumor activity in the murine L1210 model

\begin{tabular}{|c|c|c|c|c|}
\hline Group & Number of animals in the group & Treatment & Dosage, mg/kg & Total number of injections \\
\hline 1 & 6 & No treatment (NC) & - & - \\
\hline 2 & 6 & Cyclophosphamide (PC) & 50 & 2 \\
\hline 3 & 6 & $\begin{array}{c}\text { Compound 1 } \\
\text { Cyclophosphamide }\end{array}$ & $\begin{array}{c}200 \\
50\end{array}$ & 2 \\
\hline 4 & 6 & Compound 1 & 200 & 7 \\
\hline 5 & 6 & Compound 2 & 150 & 7 \\
\hline 6 & 6 & Cyclophosphamide & 50 & 7 \\
\hline 7 & 6 & Compound 2 & 150 & 7 \\
\hline 8 & 6 & Compound 3 & 250 & 7 \\
\hline
\end{tabular}

Note: NC - negative control; PC - positive control.

4-aminopiperidine derivatives for 7 days; the first injection was administered the day after inoculation. Mice with B16 melanoma received daily intraperitoneal injections of the synthesized compounds for 10 days; the first injection was administered 48 $\mathrm{h}$ after inoculation. The formulations were prepared in a laminar flow cabinet using a ready-to-use sterile normal saline solution.

\section{Statistical analysis}

The efficacy of treatment was evaluated relative to the outcomes in the NC group (inoculated mice, no treatment received). We compared the increase in the survival time, tumor growth delay and a related T/C parameter [6]. The increase in survival time and tumor growth delay were calculated from the average tumor volume at a specific point in time after inoculation (for B16 melanoma) and the survival time within the experiment (for both cancers). Differences between the studied parameters were measured using the approach of a function or several random variables [7]. Mean squared deviations (MSD) were calculated for the tumor volume at a specific point in time after inoculation (for B16 melanoma) and survival time within the observation period (both cancers). Based on mean values, MSDs and sample sizes (the number of animals in the groups), mathematical expectations (ME), 95\% Cl for tumor growth delay (TGD) and survival time increase (STI) were calculated using a code written in Mathematica 9 [7].

\section{RESULTS}

\section{Efficacy of synthesized 4-aminopiperidine derivatives in L1210 lymphocytic leukemia model}

Prior to evaluating the efficacy of $\mathrm{N}$-(2-chlorobenzyl)-N-ethyl-1(2-(methylthio)pyrimidin-4-yl)piperidin-4-amine (compound 1), 4-((methyl(1-(2-(methylthio)pyrimidin-4-yl) piperidin-4yl)amino)methyl) benzonitrile (compound 2) and N-(2,6dichlorobenzyl)-1-(1-(2-(ethylthio)pyrimidin-4-yl)piperidin-4yl)-N-methylmethaneamine (compound 3), we conducted a series of preliminary experiments to determine their maximum tolerated dose (MTD, single intraperitoneal injection) for BDF1 $\left(\mathrm{C}_{57} \mathrm{Bl} / 6 \times \mathrm{DBA} / 2\right)$ hybrid mice. After the injection, the animals were closely monitored and their weight was measured daily for 7 days. Based on clinical observations and weight dynamics, MTDs for compounds 1, 2 and 3 were $250 \mathrm{mg} / \mathrm{kg}, 200 \mathrm{mg} /$ $\mathrm{kg}$ and $300 \mathrm{mg} / \mathrm{kg}$, respectively. At these doses, the tested compounds increased the heart rate, induced rapid breathing and provoked clonic or tonic seizures in most experimental animals. These symptoms resolved within 10-15 min after the

Table 2. Antitumor activity of 3 synthesized compounds administered intraperitoneally to mice with transplantable L1210

\begin{tabular}{|c|c|c|c|c|c|}
\hline \multirow{2}{*}{ Group } & \multirow{2}{*}{ Treatment } & \multicolumn{2}{|c|}{ STI, \% } & \multicolumn{2}{|c|}{$\mathrm{T} / \mathrm{C}$} \\
\hline & & $I^{*}$ & II & 1 & II \\
\hline 1 & No treatment (NC) & \multicolumn{2}{|c|}{-} & \multicolumn{2}{|c|}{-} \\
\hline \multirow{2}{*}{2} & \multirow{2}{*}{$\mathrm{CPA}^{\star \star}(\mathrm{PC})$} & 31 & 43 & 131 & 143 \\
\hline & & \multicolumn{2}{|c|}{$37^{* \star *}$} & \multicolumn{2}{|c|}{137} \\
\hline \multirow{2}{*}{3} & \multirow{2}{*}{ Compound $1+$ CPA } & 60 & 71 & 160 & 171 \\
\hline & & \multicolumn{2}{|c|}{65,5} & \multicolumn{2}{|c|}{166} \\
\hline \multirow{2}{*}{4} & \multirow{2}{*}{ Compound 1} & 10 & 17 & 110 & 117 \\
\hline & & \multicolumn{2}{|c|}{13,5} & \multicolumn{2}{|c|}{114} \\
\hline \multirow{2}{*}{5} & \multirow{2}{*}{ Compound $2+$ CPA } & 63 & 80 & 163 & 180 \\
\hline & & \multicolumn{2}{|c|}{71,5} & \multicolumn{2}{|c|}{172} \\
\hline \multirow{2}{*}{6} & \multirow{2}{*}{ Compound 2} & 5 & 11 & 105 & 111 \\
\hline & & \multicolumn{2}{|c|}{8,0} & \multicolumn{2}{|c|}{108} \\
\hline \multirow{2}{*}{7} & \multirow{2}{*}{ Compound $3+$ CPA } & 72 & 82 & 172 & 182 \\
\hline & & \multicolumn{2}{|c|}{77,0} & \multicolumn{2}{|c|}{177} \\
\hline \multirow{2}{*}{8} & \multirow{2}{*}{ Compound 3} & 0 & 5 & 100 & 105 \\
\hline & & \multicolumn{2}{|c|}{2,5} & \multicolumn{2}{|c|}{103} \\
\hline
\end{tabular}

Note: ${ }^{*}$ — experiment number; ${ }^{* *}$ — cyclophosphamide; ${ }^{* \star *}$ - mean value. 
Table 3. Mathematical expectations (ME) for STI and their 95\% Cl

\begin{tabular}{|c|c|c|c|}
\hline Group & Treatment & $\begin{array}{l}\text { I }^{*} \\
\text { ME for STI, \% } \\
{[C I] \%}\end{array}$ & $\begin{array}{c}\text { II } \\
\text { ME for STI, \% } \\
{[\mathrm{Cl}] \%}\end{array}$ \\
\hline 1 & No treatment (NC) & - & - \\
\hline 2 & $\mathrm{CPA} * *(\mathrm{PC})$ & $\begin{array}{c}32 \\
{[6 ; 66]}\end{array}$ & $\begin{array}{c}43 \\
{[29 ; 60]}\end{array}$ \\
\hline 3 & Compound 1 + CPA & $\begin{array}{c}62 \\
{[23 ; 110]}\end{array}$ & $\begin{array}{c}71 \\
{[48 ; 98]}\end{array}$ \\
\hline 4 & Compound 1 & $\begin{array}{c}11 \\
{[-17 ; 46]}\end{array}$ & $\begin{array}{c}17 \\
{[-4 ; 40]}\end{array}$ \\
\hline 5 & Compound 2 + CPA & $\begin{array}{c}64 \\
{[34 ; 104]}\end{array}$ & $\begin{array}{c}80 \\
{[62 ; 100]}\end{array}$ \\
\hline 6 & Compound 2 & $\begin{array}{c}6 \\
{[-21 ; 40]}\end{array}$ & $\begin{array}{c}11 \\
{[-7 ; 30]}\end{array}$ \\
\hline 7 & Compound 3 + CPA & $\begin{array}{c}74 \\
{[37 ; 121]}\end{array}$ & $\begin{array}{c}82 \\
{[61 ; 106]}\end{array}$ \\
\hline 8 & Compound 3 & $\begin{array}{c}5 \\
{[-25 ; 41]}\end{array}$ & $\begin{array}{c}11 \\
{[-16 ; 40]}\end{array}$ \\
\hline
\end{tabular}

Note: ${ }^{*}$ — experiment number; ${ }^{\star *}$ — cyclophosphamide.

injection. During the first 2-3 days after the injection, half of the animals lost $2-8 \%$ of their weight. By the end of the observation period, all animals had gained weight.

Considering the obtained MTDs and the guidelines on primary antitumor activity testing [8], we selected the following dosing regimen for the animals inoculated with L1210 cells: compound 1 - $200 \mathrm{mg} / \mathrm{kg}$, compound 2 - $150 \mathrm{mg} / \mathrm{kg}$, compound 3 - $250 \mathrm{mg} / \mathrm{kg}$. The compounds were administered intraperitoneally, daily, for 7 days. The first injection was administered $24 \mathrm{~h}$ after inoculation. The animals were divided into 8 groups (6 animals per group except for the NC group, which consisted of 8 animals). The NC group did not receive any treatment. The positive control (PC) group was treated with cyclophosphamide (Table 1).

The results generated by a series of 2 experiments conducted on the L1210 model are provided in Table 2. Ranges and mean values for STI and T/C were used as repeatability indicators.

As seen from Table 2, a relatively high increase in the survival time was achieved only when the tested doses of compounds 1, 2 and 3 were used in combination with cyclophosphamide.

For L1210 lymphocytic leukemia, compounds 2 and 3 used in combination with the cytotoxic drug fall into the low therapeutic potential category (designated as + ; T/C $\geq 175 \%$ ) [6].

A potentiating effect was demonstrated by compounds 1, 2 and 3 used in combination with cyclophosphamide.

Table 3 shows mathematical expectations for STI and their 95\% Cl in the L1210 model.

Table 4. Primary antitumor activity tests conducted on the B16 melanoma model

\begin{tabular}{|c|c|c|c|c|}
\hline Group & Number of animals in the group & Treatment & Dose, mg/kg & Total number of injections \\
\hline 1 & 8 & No treatment (NC) & - & - \\
\hline 2 & 6 & Cyclophosphamide (PC) & 80 & 3 \\
\hline 3 & 6 & $\begin{array}{c}\text { Compound } 1+ \\
\text { Cyclophosphamide }\end{array}$ & $\begin{array}{c}200 \\
80\end{array}$ & $\begin{array}{c}10 \\
3\end{array}$ \\
\hline 4 & 6 & Compound 1 & 200 & 10 \\
\hline 5 & 6 & $\begin{array}{c}\text { Compound } 2+ \\
\text { Cyclophosphamide }\end{array}$ & $\begin{array}{c}150 \\
80\end{array}$ & $\begin{array}{c}10 \\
3\end{array}$ \\
\hline 6 & 6 & Compound 2 & 150 & 10 \\
\hline 7 & 6 & $\begin{array}{c}\text { Compound } 3+ \\
\text { Cyclophosphamide }\end{array}$ & $\begin{array}{c}250 \\
80\end{array}$ & $\begin{array}{c}10 \\
3\end{array}$ \\
\hline 8 & 6 & Compound 3 & 250 & 10 \\
\hline
\end{tabular}

Considering $\mathrm{Cl}$ shown in Table 3 , it can be concluded that differences in STI were significant $(p=0.05)$ between groups 2 and 5 and between groups 2 and 7 in experiment II.

\section{Efficacy of synthesized 4-aminopiperidine derivatives in B16 melanoma model}

Based on the results of antitumor activity tests conducted on the L1210 leukemia model, we selected the following dosing regimen for the B16 melanoma model: compound $1-200 \mathrm{mg} / \mathrm{kg}$, compound $2-150 \mathrm{mg} / \mathrm{kg}$, compound $3-250 \mathrm{mg} / \mathrm{kg}$. The compounds were administered intraperitoneally, daily, over the course of 10 days. The first injection was administered $48 \mathrm{~h}$ after inoculation. The animals were divided into 8 groups (6 animals per group except for the NC group, which consisted of 8 animals). The NC group did not receive any treatment. The PC group was treated with cyclophosphamide (Table 4).

The results generated by a series of 2 experiments conducted on the B16 melanoma model are provided in Table 5. Ranges (STI and TGD) and mean values (TGD) were used as repeatability indicators.

As seen from Table 5, relatively high TGD levels were achieved only when the tested doses of compounds 1,2 and 3 were used in combination with cyclophosphamide.

For solid B16 melanoma, compounds 1,2 and 3 used in combination with the cytotoxic drug fall into the low therapeutic potential category (designated as +; TGD < 51-80\%) or the 
Table 5. Antitumor activity of 3 synthesized compounds administered intraperitoneally to mice with transplantable B16 melanoma measured in a series of 2 experiments

\begin{tabular}{|c|c|c|c|c|c|c|c|c|c|c|c|}
\hline \multirow{3}{*}{ Group } & \multirow{3}{*}{ Treatment } & \multicolumn{8}{|c|}{ TGD, \% } & \multirow{2}{*}{\multicolumn{2}{|c|}{ STI, \% }} \\
\hline & & \multicolumn{2}{|c|}{ Day 13} & \multicolumn{2}{|c|}{ Day 21} & \multicolumn{2}{|c|}{ Day 28} & \multicolumn{2}{|c|}{ Day 33} & & \\
\hline & & $I^{*}$ & II & I & II & I & II & 1 & II & 1 & II \\
\hline 1 & No treatment (NC) & \multicolumn{2}{|c|}{-} & \multicolumn{2}{|c|}{-} & \multicolumn{2}{|c|}{-} & \multicolumn{2}{|c|}{-} & \multicolumn{2}{|c|}{-} \\
\hline \multirow{2}{*}{2} & \multirow{2}{*}{$\mathrm{CPA}^{*}(\mathrm{PC})$} & 77 & 87 & 62 & 83 & 62 & 78 & 31 & 65 & \multirow{2}{*}{18} & \multirow{2}{*}{23} \\
\hline & & \multicolumn{2}{|c|}{$82^{\star \star *}$} & \multicolumn{2}{|c|}{72.5} & \multicolumn{2}{|c|}{70} & \multicolumn{2}{|c|}{48} & & \\
\hline \multirow{2}{*}{3} & \multirow{2}{*}{ Compound $1+$ CPA } & 71 & 93 & 67 & 86 & 52 & 76 & 40 & 66 & \multirow{2}{*}{\multicolumn{2}{|c|}{-}} \\
\hline & & \multicolumn{2}{|c|}{82} & \multicolumn{2}{|c|}{76.5} & \multicolumn{2}{|c|}{64} & \multicolumn{2}{|c|}{53} & & \\
\hline \multirow{2}{*}{4} & \multirow{2}{*}{ Compound 1} & & & \multicolumn{2}{|c|}{-} & 2 & 11 & 5 & 12 & \multirow{2}{*}{\multicolumn{2}{|c|}{-}} \\
\hline & & \multicolumn{2}{|c|}{-} & \multicolumn{2}{|c|}{-} & & & & & & \\
\hline 5 & Comnound $2+\mathrm{PA}$ & 89 & 100 & 75 & 98 & 69 & 82 & 46 & 55 & 24 & 30 \\
\hline J & 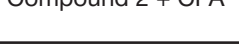 & & & & & & & & & 24 & 30 \\
\hline & Compound ? & & & & & 17 & 22 & 8 & 17 & & \\
\hline ( & 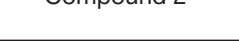 & & & & & & & & & & \\
\hline 7 & Comnound $3+$ CPA & 82 & 100 & 67 & 94 & 56 & 86 & 47 & 89 & & \\
\hline 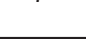 & 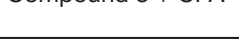 & & & & & & & & & & \\
\hline 8 & Comnound 3 & 13 & 21 & & & 15 & 28 & 12 & 18 & & \\
\hline & & & & & & & & & & & \\
\hline
\end{tabular}

Note: * experiment number; ${ }^{* *}$ — cyclophosphamide; ${ }^{* \star}$ - mean value.

Table 6. Mathematical expectations (ME) for TGD, STI and their 95\% Cls

\begin{tabular}{|c|c|c|c|c|c|c|c|}
\hline \multirow{2}{*}{ Group } & \multirow{2}{*}{ Treatment } & \multicolumn{5}{|c|}{$\begin{array}{l}\text { ME for TGD, \% } \\
{[\text { Cl] } \%}\end{array}$} & \multirow[t]{2}{*}{$\begin{array}{c}\text { ME for STI, \% } \\
\text { [Cl] \% }\end{array}$} \\
\hline & & & Day 13 & Day 21 & Day 28 & Day 33 & \\
\hline 1 & No treatment (NC) & - & & - & - & - & - \\
\hline \multirow{2}{*}{2} & \multirow{2}{*}{$\mathrm{CPA}^{*}(\mathrm{PC})$} & $I^{*}$ & 82 [23; 99] & $57[-51 ; 115]$ & $59[16 ; 83]$ & $24[-51 ; 70]$ & $22[-24 ; 86]$ \\
\hline & & ॥ & 85 [55; 95] & $80[47 ; 94]$ & $76[50 ; 91]$ & 63 [29; 82] & $29[-23 ; 112]$ \\
\hline \multirow{2}{*}{3} & \multirow{2}{*}{$\begin{array}{l}\text { Compound } 1+ \\
\text { CPA }\end{array}$} & 1 & $78[-41 ; 148]$ & $62[-14 ; 92]$ & $49[-12 ; 83]$ & $35[-46 ; 88]$ & - \\
\hline & & II & $92[75 ; 96]$ & 84 [53; 99] & 72 [38; 98] & $64[-23 ; 89]$ & - \\
\hline \multirow{2}{*}{4} & \multirow{2}{*}{ Compound 1} & 1 & - & - & $-5[-157 ; 96]$ & $-3[-122 ; 72]$ & - \\
\hline & & II & - & - & $-3[-97 ; 58]$ & $5[-82 ; 54]$ & - \\
\hline \multirow{2}{*}{5} & \multirow{2}{*}{$\begin{array}{l}\text { Compound } 2+ \\
\text { CPA }\end{array}$} & 1 & 92 [68; 95] & $71[6 ; 104]$ & $67[16 ; 102]$ & $40[-19 ; 77]$ & $28[-13 ; 89]$ \\
\hline & & II & $99[95 ; 104]$ & 98 [94; 99] & $79[57 ; 95]$ & $51[-3 ; 88]$ & $19[-10 ; 115]$ \\
\hline \multirow{2}{*}{6} & \multirow{2}{*}{ Compound 2} & 1 & - & - & $11[-108 ; 87]$ & $0[-110 ; 68]$ & - \\
\hline & & II & - & - & $9[-75 ; 65]$ & $10[-77 ; 63]$ & - \\
\hline \multirow{2}{*}{7} & \multirow{2}{*}{$\begin{array}{l}\text { Compound } 3+ \\
\text { CPA }\end{array}$} & 1 & 86 [43; 96] & $62[-20 ; 99]$ & $55[4 ; 84]$ & $42[-17 ; 77]$ & - \\
\hline & & ॥ & $99,7[95 ; 104]$ & 93 [82;97] & $84[67 ; 96]$ & 88 [78; 94] & - \\
\hline \multirow{2}{*}{8} & \multirow{2}{*}{ Compound 3} & 1 & 32 [-189; 95] & - & $9[-113 ; 86]$ & $4[-98 ; 66]$ & - \\
\hline & & ॥ & 7 [-183; 83] & - & $16[-72 ; 78]$ & $11[-66 ; 54]$ & - \\
\hline
\end{tabular}

Note: * - experiment number; ${ }^{\star *}$ — cyclophosphamide.

moderate therapeutic potential category (designated as ++; TGD < 81-90\%) on days 13, 21 and 28 after inoculation [6].

In combination with cyclophosphamide, compounds 2 and 3 demonstrated the potentiating effect with respect to TGD on day 13; compounds 1, 2 and 3 , on day 21; compound 3 , on day 33; the additive effect was demonstrated by compound 1 on day 33 , compound 2 on days 28 and 33 and compound 3 on day 28 .
A significant increase in the average survival time was observed only in the groups undergoing therapy with cyclophosphamide or cyclophosphamide + compound 2 .

This, along with the comparable efficacy of compounds 1 and 3 demonstrated on the B16 melanoma model (Table 4) and the lymphocytic leukemia model (Table 2), allowed us to single out compound 2 as the most promising candidate for further dose optimization and development of effective treatment regimens. 
Mathematical expectations for TGD, STI and their 95\% Cls are shown in Table 6.

Considering $\mathrm{Cl}$ shown in Table 6, it can be concluded that differences in TGD were significant $(p=0.05)$ between groups 2 and 5 and between groups 2 and 7 on day 13; between groups 2 and 5 on day 21 in experiment II. In all other cases of combination therapy, TGD trended towards significance.

Based on the increase in TGD and survival time achieved by applying the combination regimen vs monotherapy with cyclophosphamide (see Tables 3 and 6), compound 2 was singled out as the most promising candidate for further research.

\section{DISCUSSION}

Hsp70 inhibitors are traditionally classified by their mechanism of action and structure. As a rule, Hsp70 inhibitors bind to the nucleotide-binding domain and block the interaction of other factors with the nucleotide-binding and substrate-binding Hsp70 domains [9-11]; these agents also inhibit Hsp70 ATPase activity (the mechanisms are not specified) [12-15], selectively suppress GRP78 [16-18], interact with the EEVD Hsp70 domain [19], disrupt the interaction between Hsp70 and BAG3 [20-22], etc. At the same time, Hsp inhibitors can be grouped into the following classes by their chemical structure: ATP analogues (Ver-155008) [9, 23], dihydropyridines (MAL3101, DMT3132, NSC 630668-R/1) [14, 15, 24], flavonoids (epigallocatechin-3-gallate, quercetin) [25, 26], imidazoles (Apoptozole, Az-TPP-03) [27, 28], phenylethylsulfonamides (Pifithrin- $\mu$ ) [29, 30], rhodocyanines and their derivatives (YM-1, MKT-077, JG-98) [21, 31, 32], methylene blue [33] and some other compounds.

The compounds described in this article belong to the class of Hsp70 APTase activity inhibitors, but due to their chemical structure they have opened up a new avenue in the study of non-specific low molecular weight Hsp70 inhibitors. This study is a logical continuation of the study [4], which modeled chemical structures showing affinity for the ATP binding site of the Hsp70 molecule, described conditions for the synthesis of 4-aminopiperidine derivatives (potential Hsp70 inhibitors), analyzed their kinetic rate constants by means of surface plasmon resonance and demonstrated the inhibition of Hsp70 ATPase activity using a colorimetric test. In addition, the authors of the study screened the original collection of the synthesized compounds for their activity against 16 cancer cell lines and 2 human fibroblast cell lines. The most toxic compounds demonstrated $\mathrm{LC}_{50}$ in the range from 0.7 to $2.0 \mu \mathrm{M}$. In the acute toxicity test, one of the compounds orally administered to model mice was found to have $L_{50}$ of $870 \mathrm{mg} / \mathrm{kg}$.

Summing up, the aim of the study was achieved: we successfully evaluated the Hsp70-inhibiting potential of 4-aminopiperidine derivatives using murine models of transplantable L1210 lymphocytic leukemia and solid B16 melanoma.

\section{CONCLUSION}

As expected, our preliminary experiments showed that high doses of the synthesized 4-aminopiperidine derivatives used in combination with cyclophosphamide hold promise as chemotherapeutic drugs.

It was shown that therapy with compounds 2 and 3 resulted in significant differences in treatment efficacy $(p=0.05)$ between the groups that received combination therapy and monotherapy with cyclophosphamide. Specifically, combination therapy resulted in longer survival times in the groups with transplantable L1210 leukemia and in significant tumor growth delay on days 13 and 21 after inoculation in the groups with B16 melanoma.

Based on the obtained data, the most active compound 4-((methyl(1-(2-(methylthio)pyrimidin-4-yl) piperidin-4-yl)amino) methyl) benzonitrile formulated as a hydrochloride was selected for further optimization of dosing regimens and administration routes.

The strength of the sytotoxic effect observed in this study confirms the promise of low molecular weight Hsp inhibitors for combination therapy of cancer.

\section{References}

1. Kitano H. Cancer robustness: tumour tactics. Nature. 2003; 426: 125.

2. Taldone $T$, Kang $Y$, Patel $H$, Patel M, Patel P. Heat Shock Protein 70 Inhibitors. 2,5'-Thiodipyrimidines, 5-(Phenylthio)pyrimidines, 2-(Pyridin-3-ylthio)pyrimidines, and 3-(Phenylthio)pyridines as Reversible Binders to an Allosteric Site on Heat Shock Protein 70. J Med Chem. 2014; 57: 1208-24.

3. Kang Y, Taldone T, Patel H, Patel P. Heat Shock Protein 70 Inhibitors. 2,5'-Thiodipyrimidine and 5-(Phenylthio)pyrimidine Acrylamides as Irreversible Binders to an Allosteric Site on Heat Shock Protein 70. J Med Chem. 2014; 57: 1188-207.

4. Zeng Y, Cao R, Zhang T, Li S, Zhong W. Design and synthesis of piperidine derivatives as novel human heat shock protein 70 inhibitors for the treatment of drug-resistant tumors. European Journal of Medicinal Chemistry. 2015; 97: 19-31.

5. Aldobaev VN, Prezent MA, Zavarzin IV. Sintez N,N-dialkil-1(2-alkiltiopirimidin-4-il)piperidin-4-aminov - potencial'nyh ingibitorov belkov teplovogo shoka. Izvestija Akademii nauk. Serija himicheskaja. 2018; 11: 1-4. Russian.

6. Mironov AN, redaktory. Rukovodstvo po provedeniju doklinicheskih issledovanij lekarstvennyh sredstv, chast' pervaja. M.: FGBU «NCJeMSP» Minzdravsocrazvitija Rossii, 2012; s. 640-69. Russian.

7. Aldobaev VN, Maslikov AA, Eremenko LA, Mazanova AA. Raschet kriticheskih harakteristik raspredelenij obshheprinjatyh pokazatelej protivoopuholevoj terapii TRO i UPZh i ocenka in znachimosti

na osnove modelirovanija funkcij plotnosti raspredelenija. Toksikologicheskij vestnik. 2017; 3 (144): 2-7. Russian.

8. Sofina ZP, redaktor. Pervichnyj otbor protivoopuholevyh preparatov: metodicheskie rekomendacii. M.: MZ SSSR, 1980; s. 11-23. Russian.

9. Wen W, Liu W, Shao Y, Chen L. VER-155008, a small molecule inhibitor of HSP70 with potent anti-cancer activity on lung cancer cell lines. Exp Biol Med. 2014; 239 (5): 638-45.

10. Yu B, Yang H, Zhang X, Li H. Visualizing and quantifying the effect of the inhibition of HSP70 on breast cancer cells based on laser scanning microscopy. Technol Cancer Res Treat. 2018; 17: 1-7.

11. Tian $Y, X u H$, Faroog AA, Nie B, Chen $X$, et al. Maslinic acid induces autophagy by down-regulating HSPA8 in pancreatic cancer cells. Phytother Res. 2018; 23 (7): 1320-31.

12. Howe MK, Bodoor $\mathrm{K}$, Carlson DA, et al. Identification of an allosteric small-molecule inhibitor selective for the inducible form of heat shock protein 70. Chem Biol. 2014; 21 (12): 1648-59.

13. Wisén $\mathrm{S}$, Bertelsen EB, Thompson AD, et al. Binding of a smal molecule at a protein-protein interface regulates the chaperone activity of hsp70-hsp40. ACS Chem Biol. 2010; 5 (6): 611-22.

14. Adam C, Baeurle A, Brodsky JL, et al. The HSP70 modulator MAL3-101 inhibits Merkel cell carcinoma. PLoS One. 2014; 9 (4): e92041.

15. Wright CM, Chovatiya RJ, Jameson NE, et al. Pyrimidinonepeptoid hybrid molecules with distinct effects on molecular 
chaperone function and cell proliferation. Bioorg Med Chem. 2008; 16 (6): 3291-301.

16. Hwang JH, Kim JY, Cha MR, et al. Etoposide-resistant HT-29 human colon carcinoma cells during glucose deprivation are sensitive to piericidin A, a GRP78 down-regulator. J Cell Physiol. 2008; 215 (1): 243-50.

17. Park HR, Ryoo IJ, Choo SJ, et al. Glucose-deprived HT-29 human colon carcinoma cells are sensitive to verrucosidin as a GRP78 down-regulator. Toxicology. 2007; 229 (3): 253-61.

18. Tran PL, Kim SA, Choi HS, Yoon JH, Ahn SG. Epigallocatechin3-gallate suppresses the expression of HSP70 and HSP9O and exhibits anti-tumor activity in vitro and in vivo. BMC Cancer. 2010; 10 (1): 276

19. Ramya T, Surolia N, Surolia A. 15-Deoxyspergualin inhibits eukaryotic protein synthesis through elF2 $\alpha$ phosphorylation. Biochem J. 2007; 401 (2): 411-20.

20. Koren J, Miyata Y, Kiray J, O'Leary JC, Nguyen L, et al. Rhodacyanine derivative selectively targets cancer cells and overcomes tamoxifen resistance. PLoS One. 2012; 7 (4): e35566.

21. Colvin TA, Gabai VL, Gong J, et al. Hsp70-Bag3 interactions regulate cancer-related signaling networks. Cancer Res. 2014; 74 (17): 4731-40.

22. Li X, Colvin T, Rauch JN, et al. Validation of the Hsp70-Bag3 protein-protein interaction as a potential therapeutic target in cancer. Mol Cancer Ther. 2015; 14 (3): 642-8.

23. Tang X, Tan L, Shi K, et al. Gold nanorods together with HSP inhibitor-VER-155008 micelles for colon cancer mild-temperature photothermal therapy. Acta Pharm Sin. B. 2018; 8 (4): 587-601.

24. Fewell SW, Smith CM, Lyon MA, et al. Small molecule modulators of endogenous and co-chaperone-stimulated Hsp70 ATPase activity. J Biol Chem. 2004; 279 (49): 51131-40.

\section{Литература}

1. Kitano H. Cancer robustness: tumour tactics. Nature. 2003; 426 : 125.

2. Taldone $\mathrm{T}$, Kang $\mathrm{Y}$, Patel $\mathrm{H}$, Patel M, Patel P. Heat Shock Protein 70 Inhibitors. 2,5'-Thiodipyrimidines, 5-(Phenylthio)pyrimidines, 2-(Pyridin-3-ylthio)pyrimidines, and 3-(Phenylthio)pyridines as Reversible Binders to an Allosteric Site on Heat Shock Protein 70. J Med Chem. 2014; 57: 1208-24.

3. Kang Y, Taldone T, Patel H, Patel P. Heat Shock Protein 70 Inhibitors. 2,5'-Thiodipyrimidine and 5-(Phenylthio)pyrimidine Acrylamides as Irreversible Binders to an Allosteric Site on Heat Shock Protein 70. J Med Chem. 2014; 57: 1188-207.

4. Zeng Y, Cao R, Zhang T, Li S, Zhong W. Design and synthesis of piperidine derivatives as novel human heat shock protein 70 inhibitors for the treatment of drug-resistant tumors. European Journal of Medicinal Chemistry. 2015; 97: 19-31.

5. Алдобаев В. Н., Презент М. А., Заварзин И.В. Синтез N,Nдиалкил-1-(2-алкилтиопиримидин-4-ил)пиперидин-4-аминов - потенциальных ингибиторов белков теплового шока Известия Академии наук. Серия химическая. 2018; 11: 1-4.

6. Миронов А. Н., редакторы. Руководство по проведению доклинических исследований лекарственных средств, часть первая. М.: ФГБУ «НЦЭМСП» Минздравсоцразвития России, 2012; c. 640-69.

7. Алдобаев В. Н., Масликов А. А., Еременко Л. А., Мазанова А. А. Расчет критических характеристик распределений общепринятых показателей противоопухолевой терапии ТPO и УПЖ и оценка их значимости на основе моделирования функций плотности распределения. Токсикологический вестник. 2017: 3 (144): 2-7.

8. Софьина 3. П., редактор. Первичный отбор противоопухолевых препаратов: методические рекомендации. М.: МЗ СССР 1980; c. 11-23.

9. Wen W, Liu W, Shao Y, Chen L. VER-155008, a small molecule inhibitor of HSP70 with potent anti-cancer activity on lung cancer cell lines. Exp Biol Med. 2014; 239 (5): 638-45.

10. Yu B, Yang H, Zhang X, Li H. Visualizing and quantifying the effect of the inhibition of HSP70 on breast cancer cells based on laser
25. Ermakova SP, Kang BS, Choi BY, et al. (-) - Epigallocatechin gallate overcomes resistance to etoposide-induced cell death bytargeting the molecular chaperone glucose-regulated protein 78. Cancer Res. 2006; 66 (18): 9260-69.

26. Z-p Y, L-j C, L-y F, Tang M-h, G-I Y, et al. Liposomal quercetin efficiently suppresses growth of solid tumors in murine models. Clin Cancer Res. 2006; 12 (10): 3193-99.

27. Ko S-K, Kim J, Na DC, et al. A small molecule inhibitor of ATPase activity of HSP7O induces apoptosis and has antitumor activities. Chem Biol. 2015; 22 (3): 391-403.

28. Park S-H, Baek K-H, Shin I. Subcellular Hsp70 inhibitors promote cancer cell death via different mechanisms. Cell Chem Biol. 2018; 25 (10): 1242-54.

29. Leu J-J, Pimkina J, Pandey P, Murphy ME, George DL. HSP70 inhibition by the small-molecule 2-phenylethynesulfonamide impairs protein clearance pathways in tumor cells. Mol Cancer Res. 2011; 9 (7): 936-47.

30. Zhou Y, Ma J, Zhang J, He L, Gong J, Long C. Pifithrin- $\mu$ is efficacious against non-small cell lung cancer via inhibition of heat shock protein 70. Oncol Rep. 2017; 37 (1): 313-22.

31. Wadhwa R, Sugihara T, Yoshida A, et al. Selective toxicity of MKT077 to cancer cells is mediated by its binding to the hsp70 family protein mot-2 and reactivation of p53 function. Cancer Res. 2000; 60 (24): 6818-21.

32. Yaglom JA, Wang Y, Li A, et al. Cancer cell responses to Hsp70 inhibitor JG-98: Comparison with Hsp90 inhibitors and finding synergistic drug combinations. Sci Rep. 2018; 8 (1): 3010.

33. Wang AM, Morishima Y, Clapp KM, et al. Inhibition of hsp70 by methylene blue affects signaling protein function and ubiquitination and modulates polyglutamine protein degradation. J Biol Chem. 2010; 285 (21): 15714-23.

scanning microscopy. Technol Cancer Res Treat. 2018; 17: 1-7.

11. Tian $Y, X u H$, Faroog AA, Nie $B$, Chen $X$, et al. Maslinic acid induces autophagy by down-regulating HSPA8 in pancreatic cancer cells. Phytother Res. 2018; 23 (7): 1320-31.

12. Howe MK, Bodoor K, Carlson DA, et al. Identification of an allosteric small-molecule inhibitor selective for the inducible form of heat shock protein 70. Chem Biol. 2014; 21 (12): 1648-59.

13. Wisén $\mathrm{S}$, Bertelsen EB, Thompson AD, et al. Binding of a small molecule at a protein-protein interface regulates the chaperone activity of hsp70-hsp40. ACS Chem Biol. 2010; 5 (6): 611-22.

14. Adam C, Baeurle A, Brodsky JL, et al. The HSP70 modulator MAL3-101 inhibits Merkel cell carcinoma. PLoS One. 2014; 9 (4): e92041.

15. Wright CM, Chovatiya RJ, Jameson NE, et al. Pyrimidinonepeptoid hybrid molecules with distinct effects on molecular chaperone function and cell proliferation. Bioorg Med Chem. 2008; 16 (6): 3291-301.

16. Hwang JH, Kim JY, Cha MR, et al. Etoposide-resistant HT-29 human colon carcinoma cells during glucose deprivation are sensitive to piericidin A, a GRP78 down-regulator. J Cell Physiol. 2008; 215 (1): 243-50.

17. Park HR, Ryoo IJ, Choo SJ, et al. Glucose-deprived HT-29 human colon carcinoma cells are sensitive to verrucosidin as a GRP78 down-regulator. Toxicology. 2007; 229 (3): 253-61.

18. Tran PL, Kim SA, Choi HS, Yoon JH, Ahn SG. Epigallocatechin3-gallate suppresses the expression of HSP70 and HSP9O and exhibits anti-tumor activity in vitro and in vivo. BMC Cancer. 2010; 10 (1): 276

19. Ramya T, Surolia N, Surolia A. 15-Deoxyspergualin inhibits eukaryotic protein synthesis through elF2 $\alpha$ phosphorylation. Biochem J. 2007; 401 (2): 411-20.

20. Koren J, Miyata Y, Kiray J, O'Leary JC, Nguyen L, et al. Rhodacyanine derivative selectively targets cancer cells and overcomes tamoxifen resistance. PLoS One. 2012; 7 (4): e35566.

21. Colvin TA, Gabai VL, Gong J, et al. Hsp70-Bag3 interactions regulate cancer-related signaling networks. Cancer Res. 2014; 74 (17): 4731-40. 
22. Li X, Colvin T, Rauch JN, et al. Validation of the Hsp70-Bag3 protein-protein interaction as a potential therapeutic target in cancer. Mol Cancer Ther. 2015; 14 (3): 642-8.

23. Tang X, Tan L, Shi K, et al. Gold nanorods together with HSP inhibitor-VER-155008 micelles for colon cancer mild-temperature photothermal therapy. Acta Pharm Sin. B. 2018; 8 (4): 587-601.

24. Fewell SW, Smith CM, Lyon MA, et al. Small molecule modulators of endogenous and co-chaperone-stimulated Hsp70 ATPase activity. J Biol Chem. 2004; 279 (49): 51131-40.

25. Ermakova SP, Kang BS, Choi BY, et al. (-) - Epigallocatechin gallate overcomes resistance to etoposide-induced cell death bytargeting the molecular chaperone glucose-regulated protein 78. Cancer Res. 2006; 66 (18): 9260-69.

26. Z-p Y, L-j C, L-y F, Tang M-h, G-I Y, et al. Liposomal quercetin efficiently suppresses growth of solid tumors in murine models. Clin Cancer Res. 2006; 12 (10): 3193-99.

27. Ko S-K, Kim J, Na DC, et al. A small molecule inhibitor of ATPase activity of HSP70 induces apoptosis and has antitumor activities. Chem Biol. 2015; 22 (3): 391-403.

28. Park S-H, Baek K-H, Shin I. Subcellular Hsp70 inhibitors promote cancer cell death via different mechanisms. Cell Chem Biol. 2018; 25 (10): 1242-54

29. Leu J-J, Pimkina J, Pandey P, Murphy ME, George DL. HSP70 inhibition by the small-molecule 2-phenylethynesulfonamide impairs protein clearance pathways in tumor cells. Mol Cancer Res. 2011; 9 (7): 936-47.

30. Zhou Y, Ma J, Zhang J, He L, Gong J, Long C. Pifithrin- $\mu$ is efficacious against non-small cell lung cancer via inhibition of heat shock protein 70. Oncol Rep. 2017; 37 (1): 313-22.

31. Wadhwa R, Sugihara T, Yoshida A, et al. Selective toxicity of MKT077 to cancer cells is mediated by its binding to the hsp70 family protein mot-2 and reactivation of p53 function. Cancer Res. 2000; 60 (24): 6818-21.

32. Yaglom JA, Wang Y, Li A, et al. Cancer cell responses to Hsp70 inhibitor JG-98: Comparison with Hsp90 inhibitors and finding synergistic drug combinations. Sci Rep. 2018; 8 (1): 3010.

33. Wang AM, Morishima Y, Clapp KM, et al. Inhibition of hsp70 by methylene blue affects signaling protein function and ubiquitination and modulates polyglutamine protein degradation. J Biol Chem. 2010; 285 (21): 15714-23. 